\title{
Reconsidering the role of carbonate ion concentration in calcification by marine organisms
}

\author{
L. T. Bach \\ GEOMAR Helmholtz Centre for Ocean Research Kiel, 24105 Kiel, Germany \\ Correspondence to: L. T. Bach (lbach@geomar.de) \\ Received: 30 March 2015 - Published in Biogeosciences Discuss.: 5 May 2015 \\ Revised: 31 July 2015 - Accepted: 4 August 2015 - Published: 19 August 2015
}

\begin{abstract}
Marine organisms precipitate $0.5-2.0 \mathrm{Gt}$ of carbon as calcium carbonate $\left(\mathrm{CaCO}_{3}\right)$ every year with a profound impact on global biogeochemical element cycles. Biotic calcification relies on calcium ions $\left(\mathrm{Ca}^{2+}\right)$ and usually on bicarbonate ions $\left(\mathrm{HCO}_{3}^{-}\right)$as $\mathrm{CaCO}_{3}$ substrates and can be inhibited by high proton $\left(\mathrm{H}^{+}\right)$concentrations. The seawater concentration of carbonate ions $\left(\mathrm{CO}_{3}^{2-}\right)$ and the $\mathrm{CO}_{3}^{2-}$ dependent $\mathrm{CaCO}_{3}$ saturation state $\left(\Omega_{\mathrm{CaCO}_{3}}\right)$ seem to be irrelevant in this production process. Nevertheless, calcification rates and the success of calcifying organisms in the oceans often correlate surprisingly well with these two carbonate system parameters. This study addresses this dilemma through the rearrangement of carbonate system equations which revealed an important proportionality between $\left[\mathrm{CO}_{3}^{2-}\right]$ or $\Omega_{\mathrm{CaCO}_{3}}$ and the ratio of $\left[\mathrm{HCO}_{3}^{-}\right]$to $\left[\mathrm{H}^{+}\right]$. Due to this proportionality, calcification rates will always correlate as well with $\left[\mathrm{HCO}_{3}^{-}\right] /\left[\mathrm{H}^{+}\right]$as they do with $\left[\mathrm{CO}_{3}^{2-}\right]$ or $\Omega_{\mathrm{CaCO}_{3}}$ when temperature, salinity, and pressure are constant. Hence, $\left[\mathrm{CO}_{3}^{2-}\right]$ and $\Omega_{\mathrm{CaCO}_{3}}$ may simply be very good proxies for the control by $\left[\mathrm{HCO}_{3}^{-}\right] /\left[\mathrm{H}^{+}\right]$, where $\left[\mathrm{HCO}_{3}^{-}\right]$serves as the inorganic carbon substrate and $\left[\mathrm{H}^{+}\right]$functions as a calcification inhibitor. If the "substrate-inhibitor ratio" (i.e., $\left.\left[\mathrm{HCO}_{3}^{-}\right] /\left[\mathrm{H}^{+}\right]\right)$rather than $\left[\mathrm{CO}_{3}^{2-}\right]$ or $\Omega_{\mathrm{CaCO}_{3}}$ controls biotic $\mathrm{CaCO}_{3}$ formation, then some of the most common paradigms in ocean acidification research need to be reviewed. For example, the absence of a latitudinal gradient in $\left[\mathrm{HCO}_{3}^{-}\right] /\left[\mathrm{H}^{+}\right]$in contrast to $\left[\mathrm{CO}_{3}^{2-}\right]$ and $\Omega_{\mathrm{CaCO}_{3}}$ could modify the common assumption that high latitudes are affected most severely by ocean acidification.
\end{abstract}

\section{Introduction}

Calcium carbonate $\left(\mathrm{CaCO}_{3}\right)$ is used by a large variety of marine organisms as structural material for their exo- and endoskeletons. Calcification requires calcium ions $\left(\mathrm{Ca}^{2+}\right)$ and dissolved inorganic carbon (DIC) substrate, which is present in seawater as carbon dioxide $\left(\mathrm{CO}_{2}\right)$, bicarbonate ion $\left(\mathrm{HCO}_{3}^{-}\right)$, and carbonate ion $\left(\mathrm{CO}_{3}^{2-}\right)$. From a purely chemical point of view, calcium reacts with inorganic carbon as

$\mathrm{Ca}^{2+}+\mathrm{CO}_{3}^{2-} \rightarrow \mathrm{CaCO}_{3}$

Precipitation is thermodynamically favored when $\left[\mathrm{Ca}^{2+}\right]$ and $\left[\mathrm{CO}_{3}^{2-}\right]$ reach or exceed the solubility of $\mathrm{CaCO}_{3}$ in seawater. The stoichiometric solubility product is defined as

$\mathrm{K}_{\mathrm{sp}}^{*}=\left[\mathrm{Ca}^{2+}\right]_{\text {saturated }}\left[\mathrm{CO}_{3}^{2-}\right]_{\text {saturated }}$

and is a function of temperature, salinity, and pressure (Mucci, 1983; Zeebe and Wolf-Gladrow, 2001). The saturation state of $\mathrm{CaCO}_{3}\left(\Omega_{\mathrm{CaCO}_{3}}\right)$ is calculated with seawater concentrations of $\mathrm{Ca}^{2+}$ and $\mathrm{CO}_{3}^{2-}$ and $\mathrm{K}_{\mathrm{sp}}^{*}$ as

$\Omega_{\mathrm{CaCO}_{3}}=\frac{\left[\mathrm{Ca}^{2+}\right]_{\text {seawater }}\left[\mathrm{CO}_{3}^{2-}\right]_{\text {seawater }}}{\mathrm{K}_{\mathrm{sp}}^{*}}$.

Accordingly, $\mathrm{CaCO}_{3}$ precipitation is thermodynamically favored when the product of $\left[\mathrm{Ca}^{2+}\right]_{\text {seawater }}$ and $\left[\mathrm{CO}_{3}^{2-}\right]_{\text {seawater }}$ reaches or exceeds $\mathrm{K}_{\mathrm{sp}}^{*}$ or $\Omega_{\mathrm{CaCO}_{3}} \geq 1$. In the oceans, $\Omega_{\mathrm{CaCO}_{3}}$ is largely determined by $\left[\mathrm{CO}_{3}^{2-}\right]$ because $\left[\mathrm{Ca}^{2+}\right]$ is fairly constant in seawater (Kleypas et al., 1999).

Biogenic $\mathrm{CaCO}_{3}$ is mainly present as calcite or aragonite, which have different crystal structures and solubility. Calcite is predominantly formed by coccolithophores, foraminifera, 
and some crustaceans, while aragonite is typically found in scleractinian corals. Molluscs can have both calcite and aragonite. Echinoderms and octocorals build calcite with a large fraction of magnesium $(\mathrm{Mg})$ included in the crystal lattice (Mann, 2001). Aragonite is more soluble than calcite which is expressed in an offset between their individual $\mathrm{K}_{\mathrm{sp}}^{*}$ values (Mucci, 1983). This offset, however, is the only major difference in their solubility, and changes in $\Omega_{\text {aragonite }}$ are very similar to changes in $\Omega_{\text {calcite }}$ (Zeebe and Wolf-Gladrow, 2001). They are therefore summarized by the term $\Omega_{\mathrm{CaCO}_{3}}$ in this study since changes in the saturation state rather than absolute numbers are addressed here.

On the biological level, chemical precipitation of $\mathrm{CaCO}_{3}$ as defined in Eq. (1) is just the final step in the calcification process. Before precipitation, calcium and inorganic carbon have to be transported in a series of active and/or passive processes until they reach the site of calcification, which is usually located in specialized cellular compartments, tissues, or tissue interfaces. Transport mechanisms and pathways are highly diverse among the various calcifying taxa, which rules out the possibility of formulating a generally applicable calcification model (Mann, 2001). What all calcifiers have in common, however, is their dependency on calcium and inorganic carbon availability in seawater as this is the ultimate source medium (Weiner and Addadi, 2011). Thus, biotic calcification will respond to changes in seawater calcium and inorganic carbon when concentrations cross species-specific thresholds.

Calcium is present in seawater at high concentrations $\left(\sim 10 \mathrm{mmol} \mathrm{kg}^{-1}\right)$ as $\mathrm{Ca}^{2+}$ (Zeebe and Wolf-Gladrow, 2001). As this ion is also the form used in the final precipitation reaction (Eq. 1), calcium does not need to be chemically transformed while being transported from seawater to the site of calcification (Allemand et al., 2004; Bentov et al., 2009; Mackinder et al., 2011). This is in clear contrast to $\mathrm{CO}_{3}^{2-}$, where the relation between ion source from seawater and ion sink during crystallization is considerably more complex since $\mathrm{CO}_{3}^{2-}$ is in constant exchange with $\mathrm{HCO}_{3}^{-}$and $\mathrm{CO}_{2}$. Thus, $\mathrm{CO}_{3}^{2-}$ used for $\mathrm{CaCO}_{3}$ crystallization (Eq. 1) at the site of calcification does not have to be taken from the seawater $\mathrm{CO}_{3}^{2-}$ pool but could equally well originate from the seawater $\mathrm{CO}_{2}$ or $\mathrm{HCO}_{3}^{-}$reservoir and be transformed to $\mathrm{CO}_{3}^{2-}$ shortly before reacting with $\mathrm{Ca}^{2+}$.

Despite the unknown seawater DIC source for $\mathrm{CaCO}_{3}$ precipitation, $\left[\mathrm{CO}_{3}^{2-}\right]$ or the $\mathrm{CO}_{3}^{2-}$-dependent $\Omega_{\mathrm{CaCO}_{3}}$ are often considered a priori as the key carbonate system parameters determining calcification rates or the fitness of calcifying organisms in the oceans (Kleypas et al., 1999; Beaufort et al., 2011). This assumption is reasonable under corrosive conditions (i.e., $\Omega_{\mathrm{CaCO}_{3}}<1$ ) where $\left[\mathrm{CO}_{3}^{2-}\right]$ controls the dissolution of $\mathrm{CaCO}_{3}$ (Eq. 3). The relevance of $\left[\mathrm{CO}_{3}^{2-}\right]$ for the formation of $\mathrm{CaCO}_{3}$ is, however, poorly constrained because very little is known about a molecular uptake and transport system that can take $\mathrm{CO}_{3}^{2-}$ from seawater and trans- fer it to the site of calcification. This uncertainty leads to the key questions: which inorganic carbon species in seawater is/are utilized and which other carbonate system parameter(s) could be relevant for calcification?

Several physiological studies with different calcifying taxa have addressed these questions by setting up experiments where the influence of individual carbonate system parameters could be studied in isolation. Some of these studies found the best correlations of calcification rates with $\left[\mathrm{CO}_{3}^{2-}\right]$ and $\Omega_{\mathrm{CaCO}_{3}}$ (e.g., Schneider and Erez, 2006; Gazeau et al., 2011; de Putron et al., 2011; Keul et al., 2013; Waldbusser et al., 2014), while others highlighted the importance of $\left[\mathrm{HCO}_{3}^{-}\right]$ (e.g., Buitenhuis et al., 1999; Jury et al., 2010). Still others found that the response is not controlled by a single carbonate system parameter, but by the interplay of two or more. In coccolithophores, for example, calcification rates were repeatedly shown to increase from low to intermediate DIC but decrease again above certain thresholds (Langer et al., 2006; Bach et al., 2011, 2015; Sett et al., 2014). This optimumcurve response pattern was explained by the interaction between $\mathrm{HCO}_{3}^{-}$and protons $\left(\mathrm{H}^{+}\right)$, where $\mathrm{HCO}_{3}^{-}$stimulates calcification as substrate and $\mathrm{H}^{+}$functions as inhibitor (Bach et al., 2011, 2013). Similar conclusions have also been made in studies with bivalves (Thomsen et al., 2015) and corals (Jury et al., 2010), where it has been noted that the calcification response to changing carbonate chemistry could be the result of the opposing effects of $\left[\mathrm{HCO}_{3}^{-}\right]$and $\left[\mathrm{H}^{+}\right]$.

Jokiel (2011a, b, 2013) went one step further. Based on the results of his work on coral reef calcification he argued that single carbonate-chemistry parameters such as $\left[\mathrm{CO}_{3}^{2-}\right]$ or $\Omega_{\mathrm{CaCO}_{3}}$ have no basic physiological meaning for calcification. Instead, calcification is controlled by the interaction of a "reactant" (i.e., DIC) and an "inhibitor" (i.e., $\mathrm{H}^{+}$) and calcification rates only correlate with $\left[\mathrm{CO}_{3}^{2-}\right]$ because $\left[\mathrm{CO}_{3}^{2-}\right]$ itself is linearly correlated with the ratio of reactant to inhibitor (i.e., DIC / [H+]; Jokiel, 2013; Jokiel et al., 2014).

The present study builds upon these previous findings and aims to refine the thought that calcification is not controlled by a single carbonate-chemistry parameter but reacts to a combination of two or more. Therefore, attention will be drawn to a potentially important proportionality between $\left[\mathrm{CO}_{3}^{2-}\right]$, or $\Omega_{\mathrm{CaCO}_{3}}$, and the $\left[\mathrm{HCO}_{3}^{-}\right] /\left[\mathrm{H}^{+}\right]$ratio which was uncovered by rearranging carbonate-chemistry equations. I will discuss (1) how this proportionality could help to understand carbonate chemistry induced changes in $\mathrm{CaCO}_{3}$ precipitation by marine organisms and (2) how this proportionality could modify the paradigm that high-latitude calcifiers are more susceptible to ocean acidification than species living in low latitudes. 


\section{Material and methods}

\subsection{Uncovering the proportionality between $\left[\mathrm{CO}_{3}^{2-}\right]$, or $\Omega_{\mathrm{CaCO}_{3}}$, and the $\left[\mathrm{HCO}_{3}^{-}\right] /\left[\mathrm{H}^{+}\right]$ratio}

The carbonate system is an equilibrium reaction of the form $\mathrm{CO}_{2}+\mathrm{H}_{2} \mathrm{O} \leftrightarrow \mathrm{H}_{2} \mathrm{CO}_{3} \leftrightarrow \mathrm{HCO}_{3}^{-}+\mathrm{H}^{+} \leftrightarrow \mathrm{CO}_{3}^{2-}+2 \mathrm{H}^{+}$.

which can be simplified to

$\mathrm{CO}_{2}+\mathrm{H}_{2} \mathrm{O} \stackrel{\mathrm{K}_{1}}{\Longleftrightarrow} \mathrm{HCO}_{3}^{-}+\mathrm{H}^{+} \stackrel{\mathrm{K}_{2}}{\Longleftrightarrow} \mathrm{CO}_{3}^{2-}+2 \mathrm{H}^{+}$

because $\left[\mathrm{H}_{2} \mathrm{CO}_{3}\right]$ is only about $1 / 1000$ of $\left[\mathrm{CO}_{2}\right]$ and has no special significance for the acid-base equilibria since both species are uncharged (Butler, 1998; Dickson 2010). Hence, $\left[\mathrm{CO}_{2}\right]$ is summarized in the following as

$\left[\mathrm{CO}_{2}\right]=\left[\mathrm{CO}_{2}\right]_{\mathrm{aq}}+\left[\mathrm{H}_{2} \mathrm{CO}_{3}\right]$,

where aq denotes gaseous $\mathrm{CO}_{2}$ dissolved in seawater.

For the description of the carbonate system, the first and second dissociation constants $\left(\mathrm{K}_{1}\right.$ and $\left.\mathrm{K}_{2}\right)$ are expressed in terms of concentrations - i.e., as stoichiometric dissociation constants:

$\mathrm{K}_{1}^{*}=\frac{\left[\mathrm{HCO}_{3}^{-}\right]\left[\mathrm{H}^{+}\right]}{\left[\mathrm{CO}_{2}\right]}$

and

$\mathrm{K}_{2}^{*}=\frac{\left[\mathrm{CO}_{3}^{2-}\right]\left[\mathrm{H}^{+}\right]}{\left[\mathrm{HCO}_{3}^{-}\right]}$,

which are a function of temperature, salinity, and pressure (Zeebe and Wolf-Gladrow, 2001). Solving Eq. (8) for $\left[\mathrm{HCO}_{3}\right] /\left[\mathrm{H}^{+}\right]$as

$$
\frac{\left[\mathrm{HCO}_{3}^{-}\right]}{\left[\mathrm{H}^{+}\right]}=\frac{1}{\mathrm{~K}_{2}^{*}}\left[\mathrm{CO}_{3}^{2-}\right]
$$

shows that $\left[\mathrm{CO}_{3}^{2-}\right]$ is proportional to $\left[\mathrm{HCO}_{3}^{-}\right] /\left[\mathrm{H}^{+}\right]$when temperature, salinity, and pressure remain unchanged because $\mathrm{K}_{2}^{*}$ is constant under these circumstances.

The $\mathrm{CaCO}_{3}$ saturation state of seawater has been defined in Eq. (3). Solving Eqs. (3) and (9) for $\left[\mathrm{CO}_{3}^{2-}\right]$ yields

$\left[\mathrm{CO}_{3}^{2-}\right]=\frac{\Omega_{\mathrm{CaCO}_{3}} \mathrm{~K}_{\mathrm{sp}}^{*}}{\left[\mathrm{Ca}^{2+}\right]}$

and

$\left[\mathrm{CO}_{3}^{2-}\right]=\frac{\left[\mathrm{HCO}_{3}^{-}\right] \mathrm{K}_{2}^{*}}{\left[\mathrm{H}^{+}\right]}$.

Combining these equations and subsequently solving them for $\left[\mathrm{HCO}_{3}^{-}\right] /\left[\mathrm{H}^{+}\right]$yields

$$
\frac{\left[\mathrm{HCO}_{3}^{-}\right]}{\left[\mathrm{H}^{+}\right]}=\frac{\Omega_{\mathrm{CaCO}_{3}} \mathrm{~K}_{\mathrm{sp}}^{*}}{\left[\mathrm{Ca}^{2+}\right] \mathrm{K}_{2}^{*}} \text {. }
$$

It follows that $\left[\mathrm{HCO}_{3}^{-}\right] /\left[\mathrm{H}^{+}\right]$and $\Omega_{\mathrm{CaCO}_{3}}$ are proportional, under constant $T, S$, and $P$. Note that $\left[\mathrm{Ca}^{2+}\right]$ is conservative in seawater and therefore scales with salinity.

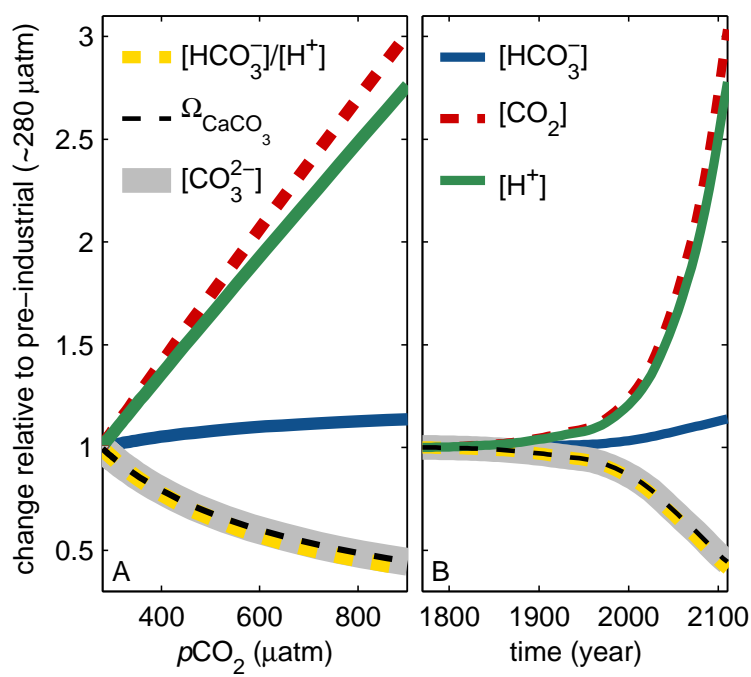

Figure 1. Change in different surface ocean carbonate-chemistry parameters under "business-as-usual" climate change scenario SRES (Special Report: Emissions Scenarios) A2 with (a) increasing atmospheric $p \mathrm{CO}_{2}$ and (b) over time. All changes are relative to the preindustrial $\mathrm{CO}_{2}$ partial pressure of $\sim 280 \mu \mathrm{atm}$. Note that the slight deviations from proportionality between $\left[\mathrm{CO}_{3}^{2-}\right], \Omega_{\mathrm{CaCO}_{3}}$, and $\left[\mathrm{HCO}_{3}^{-}\right] /\left[\mathrm{H}^{+}\right]$are the result of changes in global average temperature and salinity in the course of climate change which affect $\mathrm{K}_{2}^{*}$ and $\mathrm{K}_{\mathrm{sp}}^{*}$ (see Sect. 3.5 for further details).

\subsection{Carbonate-chemistry calculations}

Carbonate-chemistry data presented in Figs. 1-7 were calculated with the MATLAB (the Mathworks) version of CO2SYS (van Heuven et al., 2011) using $\mathrm{K}_{1}^{*}$ and $\mathrm{K}_{2}^{*}$ determined by Millero (2010), $\mathrm{K}_{\mathrm{HSO}_{4}}$ determined by Dickson (1990), and $\mathrm{K}_{\mathrm{sp}}^{*}$ determined by Mucci (1983). $\left[\mathrm{H}^{+}\right]$(free scale) was subsequently calculated from $\mathrm{pH}_{\text {free }}$ :

$\mathrm{pH}_{\text {free }}=-\log \left[\mathrm{H}^{+}\right]_{\text {free }}$,

as given in (Zeebe and Wolf-Gladrow, 2001).

Surface ocean $(0-50 \mathrm{~m})$ carbonate chemistry (DIC, TA), nutrient $\left(\mathrm{PO}_{4}^{3-}\right)$, salinity, and temperature data used for calculations presented in Figs. 1, 5b, d, and f, and 6 were extracted from a model simulation with the University of Victoria (UVic) Earth System model performed by Taucher and Oschlies (2011). In their study, the model was spun up for 4000 years with preindustrial boundary conditions and then forced with reconstructed $\mathrm{CO}_{2}$ emissions and aerosol dynamics for the period from 1765-2000 (Schmittner et al., 2008). Thereafter, the model was forced with anthropogenic $\mathrm{CO}_{2}$ emissions as predicted in the IPCC A2 ("business-asusual") scenario. Note that the data were taken from their reference run ("TEMP"). For further details on the model setup, please refer to the original description by Taucher and Oschlies (2011). 


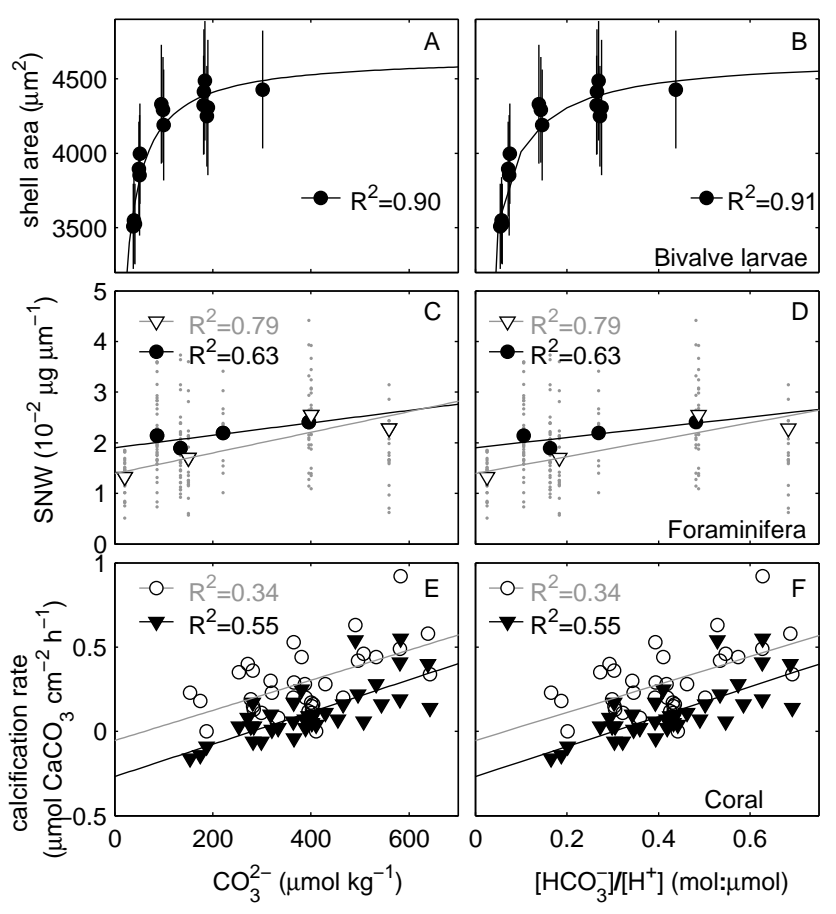

Figure 2. Correlations between calcification-related measurements and $\left[\mathrm{CO}_{3}^{2-}\right]$ (left panel) or $\left[\mathrm{HCO}_{3}\right] /\left[\mathrm{H}^{+}\right]$(right panel). Panels $(\mathbf{a}, \mathbf{b})$ : shell areas of D-veliger larvae reached 3 days after incubating embryos of the Pacific oyster Crassostrea gigas (Gazeau et al., 2011). Panels (c, d): size-normalized weight (SNW) of the foraminifer Ammonia sp. in its asexually reproducing life cycle stage (Keul et al., 2013). Black dots: constant DIC, variable $\mathrm{CO}_{2}$. White triangles: constant $\mathrm{pH}$, variable $\mathrm{CO}_{2}$. Panels $(\mathbf{e}, \mathbf{f})$ : calcification rates of the symbiont-bearing hermatypic coral Acropora eurystoma (Schneider and Erez, 2006). White dots and black triangles refer to incubations in light and darkness, respectively.

The ratios $\left[\mathrm{CO}_{3}^{2-}\right] /\left(\left[\mathrm{HCO}_{3}^{-}\right] /\left[\mathrm{H}^{+}\right]\right)$and $\left[\mathrm{CO}_{3}^{2-}\right] /\left(\mathrm{DIC} /\left[\mathrm{H}^{+}\right]\right)$shown in Fig. 3 were calculated with $\mathrm{CO} 2 \mathrm{SYS}$, assuming increasing $p \mathrm{CO}_{2}$ at constant total alkalinity $(2350 \mu \mathrm{mol} \mathrm{kg}-1)$, phosphate and silicate concentrations to be 0 , and $T, S$, and $P$ to be $15^{\circ} \mathrm{C}, 35$, and 0 dbar, respectively.

Sensitivities of $\left[\mathrm{CO}_{3}^{2-}\right], \Omega_{\mathrm{CaCO}_{3}}$, and $\left[\mathrm{HCO}_{3}^{-}\right] /\left[\mathrm{H}^{+}\right]$ to changing $P, S$, or $T$ (Fig. 4) were calculated with $\mathrm{CO} 2 \mathrm{SYS}$, assuming phosphate and silicate concentrations to be 0 , a constant $p \mathrm{CO}_{2}$ of $400 \mu \mathrm{atm}$, and a constant TA of $2350 \mu \mathrm{mol} \mathrm{kg}{ }^{1}$. The parameters that were not varied within the particular calculation were set to constant values of $15^{\circ} \mathrm{C}, 35$, and $0 \mathrm{dbar}$ for $T, S$, and $P$, respectively.

Calcification related measurements and corresponding DIC, TA, $T, S$, and nutrient data of experiments with different species (Schneider and Erez, 2006; Gazeau et al., 2011; Keul et al., 2013, Fig. 2) were downloaded from the PANGAEA data server (www.pangaea.de).

Surface ocean $(0-100 \mathrm{~m})$ carbonate chemistry, physical, and nutrient data of the meridional Atlantic transect mea-

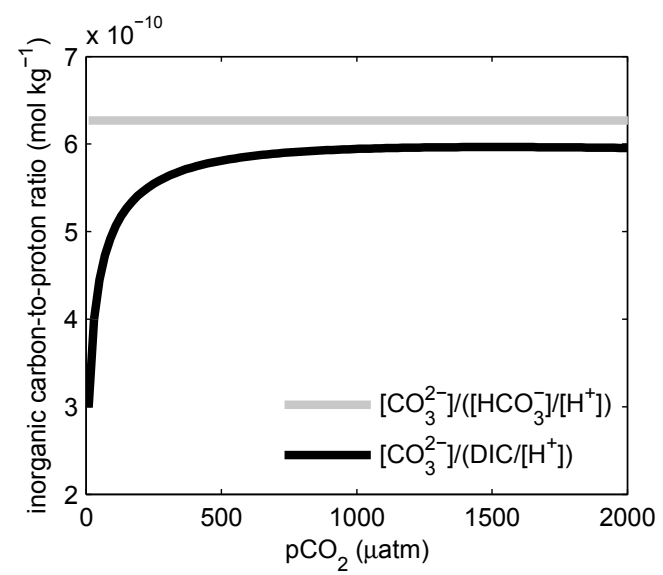

Figure 3. Ratio of $\left[\mathrm{CO}_{3}^{2-}\right]$ and $\left[\mathrm{HCO}_{3}^{-}\right] /\left[\mathrm{H}^{+}\right]$compared to the ratio of $\left[\mathrm{CO}_{3}^{2-}\right]$ and DIC / $\left[\mathrm{H}^{+}\right]$. $\left[\mathrm{CO}_{3}^{2-}\right] /\left(\left[\mathrm{HCO}_{3}^{-}\right] /\left[\mathrm{H}^{+}\right]\right)$is constant, since $\mathrm{CO}_{3}^{2-}$ and $\left[\mathrm{HCO}_{3}^{-}\right] /\left[\mathrm{H}^{+}\right]$are proportional to each other under constant temperature, salinity, and pressure (Eq. 9). In contrast, the correlation between $\left[\mathrm{CO}_{3}^{2-}\right]$ and DIC/ $\left[\mathrm{H}^{+}\right]$only works well when the majority of DIC is found in the $\mathrm{HCO}_{3}^{-}$pool. This is the case for $p \mathrm{CO}_{2}$ values larger than $\sim 250-500 \mu \mathrm{atm}$, where $\left[\mathrm{CO}_{3}^{2-}\right] /$ (DIC / $\left[\mathrm{H}^{+}\right]$) shows very little change. Below this threshold, however, the correlation starts deviating from linearity since an exponentially increasing proportion of the DIC pool is present as $\mathrm{CO}_{3}^{2-}$.

sured during CLIVAR (Climate and Ocean - Variability, Predictability, and Change) cruises in 2003 (Peltola et al., 2003) and 2005 (Wanninkhof et al., 2006; Fig. 5a, c, e) were downloaded from the CARINA (CARbon dioxide IN the Atlantic Ocean) data synthesis homepage (http://cdiac. ornl.gov/oceans/CARINA/). Water-column carbonate chemistry, physical, and nutrient data between 1988 and 2012 from the ALOHA (A Long-term Oligotrophic Habitat Assessment) time-series station (Fig. 7) in the central Pacific $\left(22^{\circ} 45^{\prime} \mathrm{N} 158^{\circ} 00^{\prime} \mathrm{W}\right)$ were downloaded from the ALOHA website (http://aco-ssds.soest.hawaii.edu/ALOHA/).

\section{Results and discussion}

\subsection{Is $\mathrm{HCO}_{3}^{-}$or $\mathrm{CO}_{3}^{2-}$ the more suitable inorganic carbon substrate for calcification?}

It is important to determine the calcification-relevant inorganic carbon species taken from seawater in order to understand the calcification response of marine organisms to changing carbonate chemistry. Most studies assume that $\mathrm{HCO}_{3}^{-}$rather than $\mathrm{CO}_{3}^{2-}$ is the key inorganic carbon ion (e.g., Allemand et al., 2004; Mackinder et al., 2010; Stumpp et al., 2012; Taylor et al., 2012). However, proof of this assumption on a physiological level is still missing because attempts to unequivocally determine the inorganic carbon molecule transported by molecular transport systems 
have not been successful so far (Pushkin and Kurtz, 2006; Mackinder et al., 2010; Lee et al., 2013; Romero et al., 2013). Furthermore, the uptake mechanisms for inorganic carbon are highly diverse among the various calcifying taxa so that generalization of physiological principles would be difficult (see Sect. 3.6 for a discussion of this topic). It may therefore be helpful to approach this question differently and ask more generally whether $\mathrm{HCO}_{3}^{-}$or $\mathrm{CO}_{3}^{2-}$ would be the more suitable inorganic carbon substrate for calcification. Three different perspectives will be addressed in the following.

\subsubsection{Abundance}

$\mathrm{HCO}_{3}^{-}$is usually the most abundant DIC species in seawater. At a $\mathrm{pH}_{\mathrm{f}}$ (free scale) of 8.1 it contributes $\sim 90 \%$ to the total DIC pool, while $\mathrm{CO}_{3}^{2-}$ contributes less than $10 \%$. Thus, molecular $\mathrm{CO}_{3}^{2-}$ transporters would require a 9 times higher affinity to their substrate than $\mathrm{HCO}_{3}^{-}$transporters. It may therefore make more sense for an organism to rely on the largest inorganic carbon pool if molecular transporters take the ions directly from seawater (Mackinder et al., 2010).

\subsubsection{Homeostasis}

The hydration timescale of $\mathrm{CO}_{2}\left(\mathrm{CO}_{2}+\mathrm{H}_{2} \mathrm{O} \leftrightarrow \mathrm{HCO}_{3}^{-}+\right.$ $\left.\mathrm{H}^{+}\right)$is comparatively slow $(\sim 10 \mathrm{~s})$, while the hydrolysis of $\mathrm{HCO}_{3}^{-}\left(\mathrm{HCO}_{3}^{-} \leftrightarrow \mathrm{CO}_{3}^{2-}+\mathrm{H}^{+}\right)$is fast $\left(\sim 10^{-7} \mathrm{~s}\right.$; Zeebe and Wolf-Gladrow, 2001; Schulz et al., 2006). Assuming a transcellular pathway, selectively incorporated $\mathrm{CO}_{3}^{2-}$ that is transported through cytosol with a typical $\mathrm{pH}$ around $\sim 7.0$ 7.4 (Madshus, 1988) would quickly turn into $\mathrm{HCO}_{3}^{-}$unless the transfer is faster than $10^{-7} \mathrm{~s}$. In the likely case that the transfer takes longer, $\mathrm{CO}_{3}^{2-}$ would bind a proton in the cytosol and be transported as $\mathrm{HCO}_{3}^{-}$to the site of calcification, where the proton would subsequently be released back to the cytosol during $\mathrm{CaCO}_{3}$ precipitation. Hence, the cytosolic $\mathrm{pH}$ would remain stable in the case of selective $\mathrm{CO}_{3}^{2-}$ uptake as long as $\mathrm{CO}_{3}^{2-}$ uptake and $\mathrm{CaCO}_{3}$ precipitation occur at the same rate. However, both processes may occasionally run out of equilibrium for short periods. In these cases, the utilization of $\mathrm{CO}_{3}^{2-}$ as an inorganic carbon source would constitute a substantial risk for the organisms' $\mathrm{pH}$ homeostasis. Excess $\mathrm{CO}_{3}^{2-}$ uptake would elevate cytosolic $\mathrm{pH}$, while excess $\mathrm{CaCO}_{3}$ precipitation would reduce it. In contrast, a selective uptake of $\mathrm{HCO}_{3}^{-}$from seawater would perturb the cytosolic $\mathrm{pH}$ to a much smaller extent when $\mathrm{HCO}_{3}^{-}$uptake and $\mathrm{CaCO}_{3}$ precipitation are not entirely balanced because $\mathrm{HCO}_{3}^{-}$has a relatively low potential to accept or donate $\mathrm{H}^{+}$ at a typical $\mathrm{pH}$ of 7.2. It may therefore be easier for calcifiers to keep cytosolic $\mathrm{pH}$ stable at $\sim 7.2$ when using $\mathrm{HCO}_{3}^{-}$.

\subsubsection{Stability}

Seawater carbonate-chemistry conditions are relatively stable on longer timescales but can fluctuate substantially on a
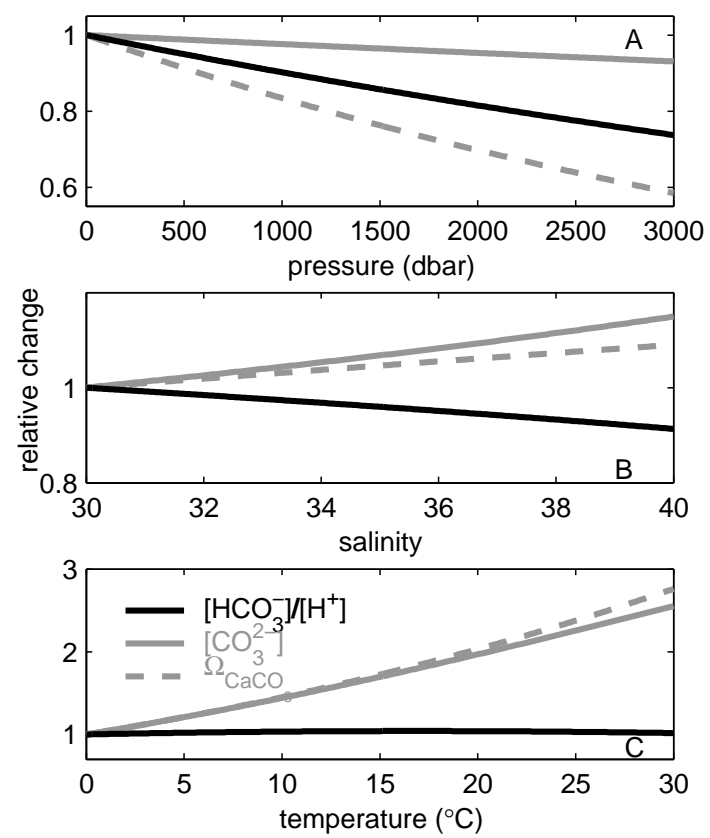

Figure 4. Relative change in $\left[\mathrm{CO}_{3}^{2-}\right], \Omega_{\mathrm{CaCO}_{3}}$, and $\left[\mathrm{HCO}_{3}^{-}\right] /\left[\mathrm{H}^{+}\right]$ on (a) a pressure gradient, (b) a temperature gradient, and (c) a salinity gradient.

seasonal and diurnal cycle (Takahashi et al., 1993; Thomsen et al., 2010; Shaw et al., 2013), especially in diffusive boundary layers of organisms (Wolf-Gladrow and Riebesell, 1997; Flynn et al., 2012; Glas et al., 2012a; Agostini et al., 2013). Fluctuations are mostly induced by photosynthetic or respiratory turnover of $\mathrm{CO}_{2}$. The magnitude of fluctuation scales with the productivity of the ecosystem (Schulz and Riebesell, 2013), but fluctuations should usually stay within the $\sim 6.5-9 \mathrm{pH}$ range. $\mathrm{HCO}_{3}^{-}$is dominant and has a relatively stable concentration in this entire $\mathrm{pH}$ range, while $\left[\mathrm{CO}_{3}^{2-}\right]$ is highly variable. In the habitat of a temperate coralline alga, for example, typical diurnal $\mathrm{pH}$ fluctuations can range from $\sim 8.4$ at day to $\sim 7.6$ at night (Cornwall et al., 2013). These changes would translate into a moderate difference between day and night of $\sim 30 \%$ in $\left[\mathrm{HCO}_{3}^{-}\right]$but a pronounced difference of more than $450 \%$ in $\left[\mathrm{CO}_{3}^{2-}\right]$. Hence, $\mathrm{HCO}_{3}^{-}$is the much more reliable inorganic carbon source for calcification as it shows significantly smaller variability.

\subsection{Relationship between calcification and $\left[\mathrm{CO}_{3}^{2-}\right]$ or $\left[\mathrm{HCO}_{3}^{-}\right] /\left[\mathrm{H}^{+}\right]$in existing data sets}

If the common assumption holds and marine calcifiers primarily utilize $\mathrm{HCO}_{3}^{-}$instead of $\mathrm{CO}_{3}^{2-}$ as $\mathrm{CaCO}_{3}$ substrate (see previous section), then correlations between calcification and $\left[\mathrm{CO}_{3}^{2-}\right]$ or $\Omega_{\mathrm{CaCO}_{3}}$ are not useful under noncorrosive conditions. Still, these correlations often yield high coefficients of determination $\left(R^{2}\right)$ even if conditions are supersaturated (Schneider and Erez, 2006; Marubini et al., 2008; 

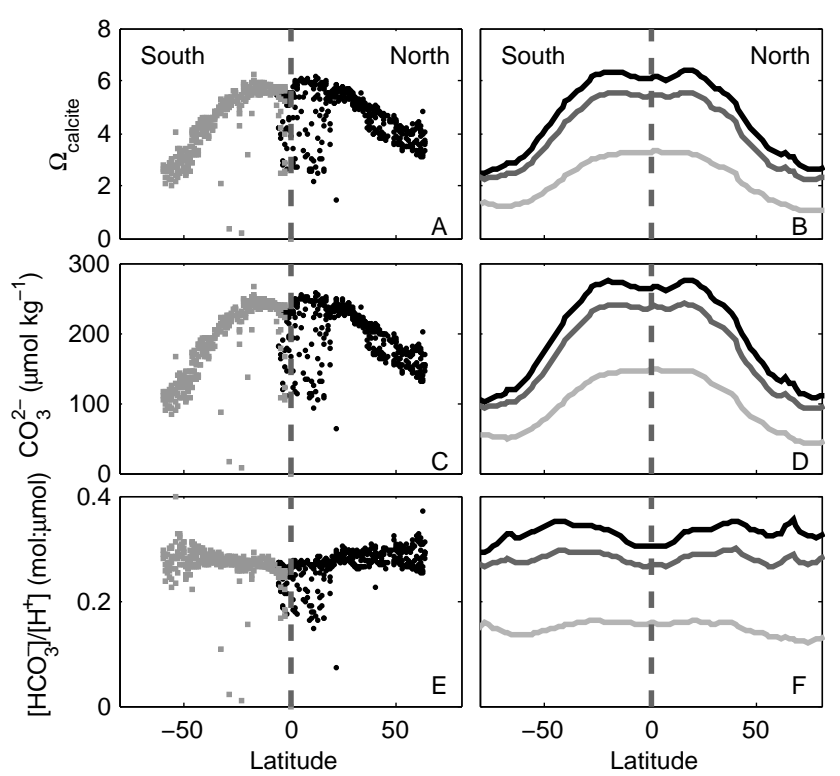

Figure 5. Change in $\Omega_{\mathrm{CaCO}_{3}},\left[\mathrm{CO}_{3}^{2-}\right]$, and $\left[\mathrm{HCO}_{3}^{-}\right] /\left[\mathrm{H}^{+}\right]$in the surface ocean along a meridional gradient. The left panels (a, c, and e) show compiled surface ocean $(0-100 \mathrm{~m})$ data from two north to south transects in the Atlantic, measured during CLIVAR $\mathrm{CO}_{2}$ cruises in 2003 (black dots) and 2005 (grey squares). The right panels (b, d, and f) show the latitudinal surface ocean $(0-50 \mathrm{~m})$ average calculated with the UVic model for the years 1770 (black line), 2000 (grey line), and 2100 (light grey line). The dashed vertical line illustrates the equator.

de Putron et al., 2011; Gazeau et al., 2011; Keul et al., 2013; Waldbusser et al., 2014). This dilemma can be resolved when considering the proportionality between $\left[\mathrm{CO}_{3}^{2-}\right], \Omega_{\mathrm{CaCO}_{3}}$, and $\left[\mathrm{HCO}_{3}^{-}\right] /\left[\mathrm{H}^{+}\right]$derived above. Every correlation between calcification and $\left[\mathrm{CO}_{3}^{2}\right]$ or $\Omega_{\mathrm{CaCO}_{3}}$ will be identical to the corresponding correlation with $\left[\mathrm{HCO}_{3}^{-}\right] /\left[\mathrm{H}^{+}\right]$when $T, S$, and $P$ are stable (see Eqs. 9 and 12).

This is illustrated with data from three publications where the influence of different carbonate-chemistry parameters on calcification rates was disentangled (Schneider and Erez, 2006; Gazeau et al., 2011; Keul et al., 2013; Fig. 2). All three studies conclude that $\left[\mathrm{CO}_{3}^{2-}\right]$ determines calcification rates although calcification rates or calcification related measurements of the hermatypic coral Acropora eurystoma (Schneider and Erez, 2006), the benthic foraminifer Ammonia sp. (Keul et al., 2013), and larvae of the Pacific oyster Crassostrea gigas (Gazeau et al., 2011) correlate equally well to $\left[\mathrm{HCO}_{3}^{-}\right] /\left[\mathrm{H}^{+}\right]$.

\subsection{Conceptual basis for the calcification control of $\left[\mathrm{HCO}_{3}^{-}\right] /\left[\mathrm{H}^{+}\right]$}

Implicit in the $\left[\mathrm{HCO}_{3}^{-}\right] /\left[\mathrm{H}^{+}\right]$ratio is the thought that biotic $\mathrm{CaCO}_{3}$ precipitation is balanced by the stimulating influence of an inorganic carbon substrate and the negative influence of

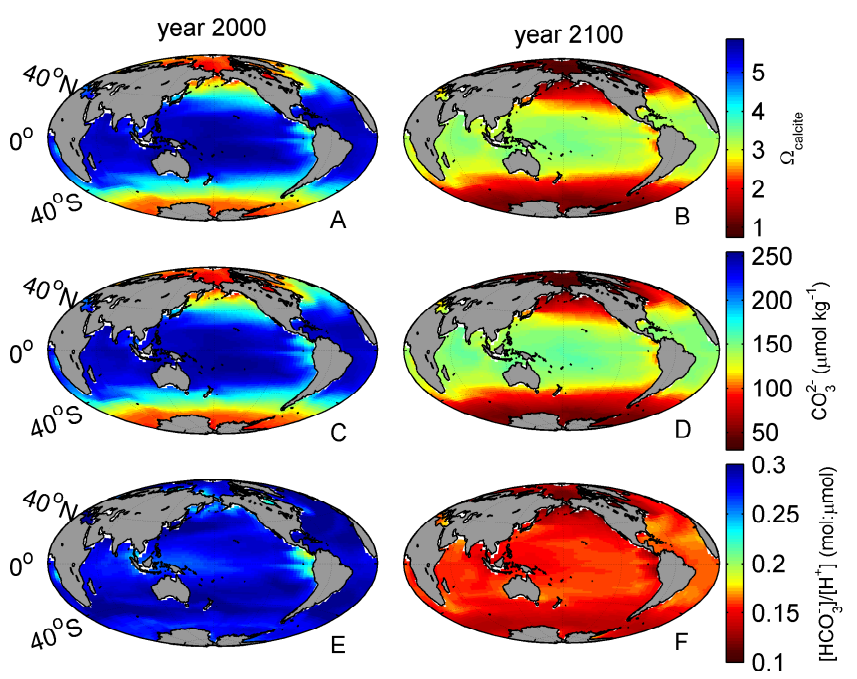

Figure 6. Surface ocean $(0-50 \mathrm{~m}) \Omega_{\mathrm{CaCO}_{3}}(\mathbf{a}, \mathbf{b}),\left[\mathrm{CO}_{3}^{2-}\right]$ (c, d), and $\left[\mathrm{HCO}_{3}^{-}\right] /\left[\mathrm{H}^{+}\right](\mathbf{e}, \mathbf{f})$ in the year 2000 (left panel) compared to 2100 (right panel) calculated with the UVic model. The pronounced latitudinal gradient of $\Omega_{\mathrm{CaCO}_{3}}$ and $\left[\mathrm{CO}_{3}^{2-}\right]$ is absent in $\left[\mathrm{HCO}_{3}^{-}\right] /\left[\mathrm{H}^{+}\right]$(see also Fig. 5). $\left[\mathrm{HCO}_{3}^{-}\right] /\left[\mathrm{H}^{+}\right]$is quite homogeneous in 2000 and 2100 in all major ocean basins, with only some regional anomalies. These are found in some coastal areas (e.g., in the Bering Sea) and in eastern boundary upwelling systems, most noticeably off the west coast of South and Central America.

an inhibitor (Bach et al., 2011, 2013, 2015; Jokiel, 2011a, b, 2013; Jokiel et al., 2014). Higher $\left[\mathrm{HCO}_{3}^{-}\right]$would stimulate calcification rates as a substrate, whereas high seawater $\left[\mathrm{H}^{+}\right]$ would inhibit them.

When both $\left[\mathrm{HCO}_{3}^{-}\right]$and $\left[\mathrm{H}^{+}\right]$increase, calcification is balanced by the degree of change in these two ions. $\left[\mathrm{H}^{+}\right]$increases profoundly under ocean acidification, while $\left[\mathrm{HCO}_{3}^{-}\right]$ increases only marginally (Fig. 1; see also Schulz et al., 2009). Here, changing $\left[\mathrm{H}^{+}\right]$should be of dominant control (Bach et al., 2011). When increasing $\left[\mathrm{H}^{+}\right]$is paralleled by a significant increase in $\left[\mathrm{HCO}_{3}^{-}\right]$, the additional bicarbonate could potentially compensate the inhibitory proton effect to some extent (Bach et al., 2015). Indeed, $\mathrm{HCO}_{3}^{-}$uptake is a common mechanism to buffer acidosis and might be facilitated at higher $\mathrm{HCO}_{3}^{-}$availability (Boron, 2004; Melzner et al., 2009; Stumpp et al., 2012).

The inhibition by high seawater $\left[\mathrm{H}^{+}\right]$is tightly linked to the production of $\mathrm{CaCO}_{3}$ from $\mathrm{Ca}^{2+}$ and $\mathrm{HCO}_{3}^{-}$because calcification is then a source of $\mathrm{H}^{+}\left(\mathrm{Ca}^{2+}+\mathrm{HCO}_{3} \rightarrow \mathrm{CaCO}_{3}+\right.$ $\left.\mathrm{H}^{+}\right) . \mathrm{H}^{+}$generated that way would subsequently have to be released back into seawater to avoid acidification at the site of calcification. This removal should be relatively easy when seawater $\left[\mathrm{H}^{+}\right]$is low (i.e., $\mathrm{pH}$ is high). It could become more difficult, however, when seawater $\left[\mathrm{H}^{+}\right]$rises and the inside-out $\left[\mathrm{H}^{+}\right]$gradient shrinks (Cyronak et al., 2015; Jokiel, 2011b; Taylor et al., 2011; Stumpp et al., 2012; Venn et al., 2013). 


\subsection{Similarities and differences between the DIC / $\left[\mathrm{H}^{+}\right]$ and the $\left[\mathrm{HCO}_{3}^{-}\right] /\left[\mathrm{H}^{+}\right]$ratio}

In a series of papers Jokiel (2011a, b, 2013) proposed that carbonate chemistry controls calcification rates in corals through the combined influence of DIC ("reactant") and $\mathrm{H}^{+}$ ("inhibitor") and noted that favorable carbonate-chemistry conditions are established when the ratio of DIC to $\left[\mathrm{H}^{+}\right]$ is high. Hence, the underlying thought implicit in the DIC $/\left[\mathrm{H}^{+}\right]$ratio is identical to that implemented in the "substrate-inhibitor ratio" defined here as $\left[\mathrm{HCO}_{3}^{-}\right] /\left[\mathrm{H}^{+}\right]$.

Jokiel $(2011 \mathrm{a}, \mathrm{b}, 2013)$ also noted that there is a linear correlation between DIC / $\left[\mathrm{H}^{+}\right]$and $\left[\mathrm{CO}_{3}^{2-}\right]$. The correlation observed by Jokiel exists because the DIC pool is dominated by $\mathrm{HCO}_{3}^{-}$ions under normal $\mathrm{pH}$ conditions (see Sect. 3.1.1) and therefore typically follows the same rules as the proportionality between $\left[\mathrm{HCO}_{3}^{-}\right] /\left[\mathrm{H}^{+}\right]$and $\left[\mathrm{CO}_{3}^{2-}\right]$ uncovered in Sect. 2.1. However, when the fraction of $\mathrm{HCO}_{3}^{-}$in the DIC pool declines, the DIC / $\left[\mathrm{H}^{+}\right]$vs. $\left[\mathrm{CO}_{3}^{2-}\right]$ correlation starts to increasingly deviate from linearity. In the oceans, noticeable deviations start in the $p \mathrm{CO}_{2}$ range below 250-500 $\mu \mathrm{atm}$, where an exponentially increasing fraction of the DIC pool is present as $\mathrm{CO}_{3}^{2-}$ (Fig. 3). Thus, exchanging DIC / $\left[\mathrm{H}^{+}\right]$ with $\left[\mathrm{CO}_{3}^{2-}\right]$ to explain the calcification response to carbonate chemistry (comparable to what has been done in Fig. 2) is not meaningful when $p \mathrm{CO}_{2}$ is below this range. This problem does not exist for the $\left[\mathrm{HCO}_{3}^{-}\right] /\left[\mathrm{H}^{+}\right]$ratio where the linear relation holds under all carbonate-chemistry conditions as long as $T, S$, and $P$ are constant (Fig. 3).

Whether the DIC $/\left[\mathrm{H}^{+}\right]$ratio proposed by Jokiel (2011a, $\mathrm{b}, 2013)$ or the $\left[\mathrm{HCO}_{3}^{-}\right] /\left[\mathrm{H}^{+}\right]$ratio could be the more meaningful parameter to explain the carbonate-chemistry response of calcification depends on the investigated organism. The DIC / $\left[\mathrm{H}^{+}\right]$ratio would be more meaningful if the organism takes up all DIC species in the same proportion as present in seawater while the $\left[\mathrm{HCO}_{3}^{-}\right] /\left[\mathrm{H}^{+}\right]$ratio would be more appropriate when selective uptake on $\mathrm{HCO}_{3}^{-}$occurs (see also Sect. 3.6.4).

\subsection{Global implications}

The following paragraphs will address to what extent our view of the carbonate-chemistry control of calcification in the oceans could be modified when we consider $\left[\mathrm{HCO}_{3}^{-}\right] /\left[\mathrm{H}^{+}\right]$rather than $\left[\mathrm{CO}_{3}^{2-}\right]$ or $\Omega_{\mathrm{CaCO}_{3}}$ as the most influential parameter. Before starting the discussion I would like to emphasize, however, that carbonate-chemistry patterns discussed here are just one among other abiotic (e.g., temperature or light) or biotic (e.g., food availability or competition) factors which must also be taken into consideration when trying to understand the patterns of calcification in the oceans.
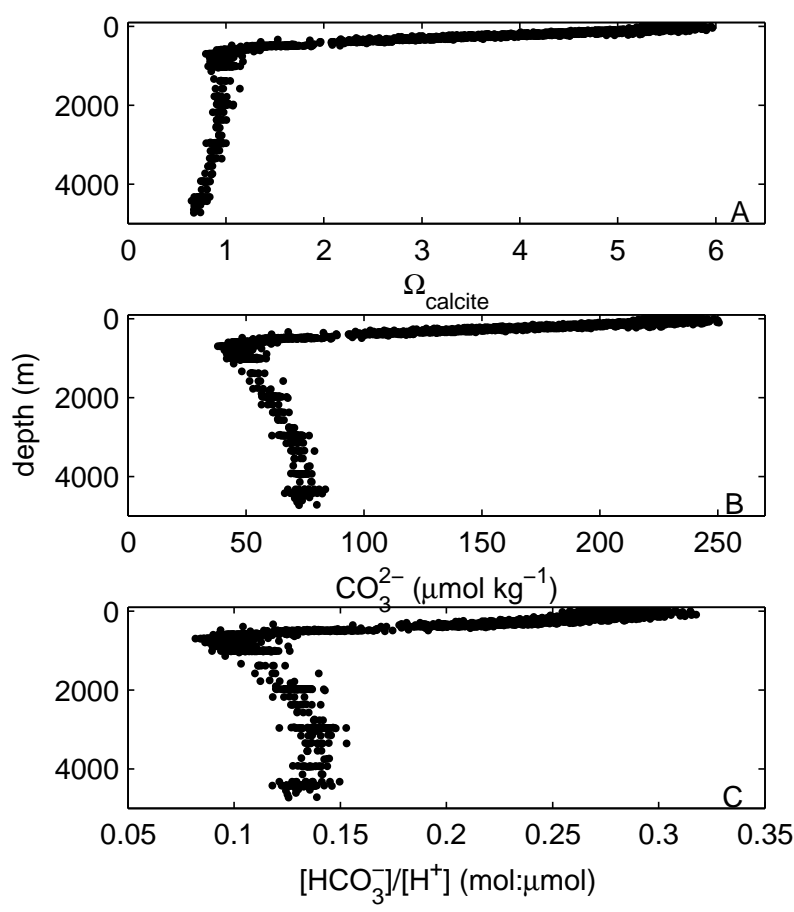

Figure 7. Change in (a) $\Omega_{\mathrm{CaCO}_{3}}$, (b) $\left[\mathrm{CO}_{3}^{2-}\right]$, and (c) $\left[\mathrm{HCO}_{3}^{-}\right] /\left[\mathrm{H}^{+}\right]$on a depth gradient at ALOHA time-series station near Hawaii $\left(22^{\circ} 45^{\prime} \mathrm{N} 158^{\circ} 00^{\prime} \mathrm{W}\right)$. Compiled data from 1988-2012 which was downloaded from the ALOHA website.

\subsubsection{Latitudinal and vertical gradients in $\left[\mathrm{HCO}_{3}^{-}\right] /\left[\mathrm{H}^{+}\right],\left[\mathrm{CO}_{3}^{2-}\right]$, and $\Omega_{\mathrm{CaCO}_{3}}$}

The proportionality between $\left[\mathrm{CO}_{3}^{2-}\right], \quad \Omega_{\mathrm{CaCO}_{3}}$, and $\left[\mathrm{HCO}_{3}^{-}\right] /\left[\mathrm{H}^{+}\right]$derived in Sect. 2.1 is only valid as long temperature, salinity, and pressure are constant and do not alter $\mathrm{K}_{2}^{*}$ and $\mathrm{K}_{\mathrm{sp}}^{*}$. If these parameters change, then the proportionality no longer holds and the response of calcification would be different, depending on whether calcifiers react to $\left[\mathrm{CO}_{3}^{2-}\right], \Omega_{\mathrm{CaCO}_{3}}$, or $\left[\mathrm{HCO}_{3}^{-}\right] /\left[\mathrm{H}^{+}\right]$.

The influence of temperature, salinity, and pressure is illustrated in Fig. 4. Increasing pressure has a negative effect on all three carbonate system components. It is most pronounced on $\Omega_{\mathrm{CaCO}_{3}}$ and weakest on $\left[\mathrm{CO}_{3}^{2-}\right]$ (Fig. 4a). Increasing salinity has a positive influence on $\left[\mathrm{CO}_{3}^{2-}\right]$ and $\Omega_{\mathrm{CaCO}_{3}}$ but a negative one on $\left[\mathrm{HCO}_{3}^{-}\right] /\left[\mathrm{H}^{+}\right]$(Fig. $4 \mathrm{~b}$ ). Its influence, however, is low since salinity gradients in the oceans are generally too weak to be of high relevance in this context. Increasing temperature has a profound positive impact on $\left[\mathrm{CO}_{3}^{2-}\right]$ and $\Omega_{\mathrm{CaCO}_{3}}$ but almost no influence on $\left[\mathrm{HCO}_{3}^{-}\right] /\left[\mathrm{H}^{+}\right]$(Fig. $4 \mathrm{c}$ ).

In combination, these factors cause a highly interesting difference of $\left[\mathrm{CO}_{3}^{2-}\right], \Omega_{\mathrm{CaCO}_{3}}$, and $\left[\mathrm{HCO}_{3}\right] /\left[\mathrm{H}^{+}\right]$on a latitudinal gradient. While $\Omega_{\mathrm{CaCO}_{3}}$ and $\left[\mathrm{CO}_{3}^{2-}\right]$ decrease 2-3fold towards the poles, $\left[\mathrm{HCO}_{3}^{-}\right] /\left[\mathrm{H}^{+}\right]$is almost constant over the same range (Figs. 5, 6). This inconsistency is mostly 
due to different temperature sensitivities among the three parameters. Cooler temperatures in high latitudes lead to a higher solubility of $\mathrm{CO}_{2}$, which results in an equilibrium shift away from $\left[\mathrm{CO}_{3}^{2-}\right]$ towards $\left[\mathrm{CO}_{2}\right]$ and $\left[\mathrm{HCO}_{3}^{-}\right]$(Eq. 4). Accordingly, $\left[\mathrm{CO}_{3}^{2-}\right]$ declines towards the poles. $\Omega_{\mathrm{CaCO}_{3}}$ follows the concentration of $\mathrm{CO}_{3}^{2-}$ since $\left[\mathrm{Ca}^{2+}\right]$ is too stable to be of any relevance. The slight poleward increase in $\left[\mathrm{HCO}_{3}^{-}\right]$is balanced by the concomitant increase in $\left[\mathrm{H}^{+}\right]$ which explains the stability of $\left[\mathrm{HCO}_{3}^{-}\right] /\left[\mathrm{H}^{+}\right]$over the latitudinal gradient. Thus, carbonate-chemistry conditions for biotic $\mathrm{CaCO}_{3}$ production would be fairly constant over the entire surface ocean if controlled by $\left[\mathrm{HCO}_{3}^{-}\right] /\left[\mathrm{H}^{+}\right]$, whereas they would show a profound poleward deterioration if determined by $\left[\mathrm{CO}_{3}^{2-}\right]$ or $\Omega_{\mathrm{CaCO}_{3}}$ (Figs. 5, 6).

Vertically, $\left[\mathrm{CO}_{3}^{2-}\right]$ and $\Omega_{\mathrm{CaCO}_{3}}$ decrease more severely than $\left[\mathrm{HCO}_{3}^{-}\right] /\left[\mathrm{H}^{+}\right]$from the surface to about $1000 \mathrm{~m}$ depth ( $\sim 5$-fold vs. $\sim 3$-fold decrease; Fig. 7$)$. There are two reasons for this. First, the temperature decline, which is strongest in the upper few hundred meters, negatively affects $\left[\mathrm{CO}_{3}^{2-}\right]$ and $\Omega_{\mathrm{CaCO}_{3}}$, whereas $\left[\mathrm{HCO}_{3}^{-}\right] /\left[\mathrm{H}^{+}\right]$remains unaffected (Fig. 4c). Second, the increase in $\left[\mathrm{H}^{+}\right]$from $0-1000 \mathrm{~m}$ due to respiratory $\mathrm{CO}_{2}$ release is paralleled by $\sim 30 \%$ increases in $\left[\mathrm{HCO}_{3}^{-}\right]$, which mitigates the decline in $\left[\mathrm{HCO}_{3}^{-}\right] /\left[\mathrm{H}^{+}\right]$. Below $1000 \mathrm{~m}$, all three carbonate system parameters are relatively stable. Of the three carbonate system parameters considered here, $\left[\mathrm{HCO}_{3}^{-}\right] /\left[\mathrm{H}^{+}\right]$is the most homogeneous when comparing the development over the entire water column. Thus, the deterioration of carbonate-chemistry conditions for biotic $\mathrm{CaCO}_{3}$ formation with depth would be less pronounced if it was controlled by $\left[\mathrm{HCO}_{3}^{-}\right] /\left[\mathrm{H}^{+}\right]$(Fig. 7).

\subsubsection{Implications for ocean acidification research}

The ongoing perturbation of the surface ocean by anthropogenic $\mathrm{CO}_{2}$ causes a decline in $\Omega_{\mathrm{CaCO}_{3}},\left[\mathrm{CO}_{3}^{2-}\right]$, and $\left[\mathrm{HCO}_{3}^{-}\right] /\left[\mathrm{H}^{+}\right]$. The magnitude of change in all three parameters is very similar on the global average (Fig. 1). Until 2100 they decrease to about half the value of the year 2000 (Figs. 1, 5). The two different latitudinal patterns for $\Omega_{\mathrm{CaCO}_{3}},\left[\mathrm{CO}_{3}^{2-}\right]$, or $\left[\mathrm{HCO}_{3}^{-}\right] /\left[\mathrm{H}^{+}\right]$are, however, conserved in the course of climate change (Fig. 6). Hence, latitudinal differences among the three parameters prevail for longer timescales and are not restricted to the currents status of the carbonate system.

The presence of two highly different latitudinal patterns has important implications for ocean acidification research. Polar regions have been identified as the most severely acidification-affected regions on Earth as they are the first to experience corrosive conditions (i.e., $\Omega_{\mathrm{CaCO}_{3}}<1$; Orr et al., 2005; Fabry et al., 2009; Hofmann et al., 2010). The vulnerability of high latitudes is therefore explained by an abiotic process - i.e., $\mathrm{CaCO}_{3}$ dissolution. The study presented here deals with controls on the opposite process - i.e., biotic $\mathrm{CaCO}_{3}$ formation. Dissolution is determined by $\Omega_{\mathrm{CaCO}_{3}}$ and there is no doubt that polar regions are the most severely affected (see also Fig. 6). From the production perspective, however, this is not necessarily the case. Ocean acidification would be equally harmful in warm-water habitats and in the polar realm in the case of $\mathrm{CaCO}_{3}$ formation being controlled by $\left[\mathrm{HCO}_{3}^{-}\right] /\left[\mathrm{H}^{+}\right]$and not $\left[\mathrm{CO}_{3}^{2-}\right]$ or $\Omega_{\mathrm{CaCO}_{3}}$. Thus, when high-latitude organisms find a way to efficiently protect their crystal skeletons from corrosive seawater, they may not be more vulnerable to ocean acidification than their warm-water counterparts.

\subsection{Limitations and uncertainties}

This study has argued that a substrate-inhibitor ratio like $\left[\mathrm{HCO}_{3}^{-}\right] /\left[\mathrm{H}^{+}\right]$(or DIC / [H+]; Jokiel, 2011a, b, 2013) could be a useful measure to assess which carbonatechemistry conditions could be favorable for calcification. However, it must also be recognized that such a rather general view of the carbonate-chemistry control of calcification has its limitations at a more detailed physiological level. Calcification follows an enormous variety of pathways among the different taxa, with distinct inorganic carbon uptake mechanisms and distinct sensitivities to $\mathrm{H}^{+}$. Thus, the capability of the substrate-inhibitor ratio to predict calcification rates can always be confounded by taxon-specific physiological features. The most important limitations and uncertainties for the ability of $\left[\mathrm{HCO}_{3}^{-}\right] /\left[\mathrm{H}^{+}\right]$to serve as a predictor variable for the carbonate-chemistry control of calcification will be discussed in the following.

\subsubsection{Corrosive conditions - accounting for the difference between gross and net calcification}

When discussing the influence of carbonate chemistry on calcification, a distinction needs to be made between the formation and dissolution of $\mathrm{CaCO}_{3}$ since these two processes are possibly controlled by different carbonate-chemistry parameters. The roles of $\mathrm{CaCO}_{3}$ formation and dissolution are incorporated in the terms gross and net calcification. The former exclusively refers to the precipitation of $\mathrm{CaCO}_{3}$, whereas the latter accounts for both precipitation and dissolution. The ratio of $\left[\mathrm{HCO}_{3}^{-}\right]$and $\left[\mathrm{H}^{+}\right]$can potentially be very useful to determine gross calcification, which equals net calcification under noncorrosive conditions (i.e., $\Omega_{\mathrm{CaCO}_{3}}$ >1). When $\Omega_{\mathrm{CaCO}_{3}}$ falls below 1, however, the control of $\left[\mathrm{HCO}_{3}^{-}\right] /\left[\mathrm{H}^{+}\right]$on gross calcification would be obscured by the abiotic influence of $\Omega_{\mathrm{CaCO}_{3}}$ on dissolution. Accordingly, corrosive conditions would require a consideration of both $\left[\mathrm{HCO}_{3}^{-}\right] /\left[\mathrm{H}^{+}\right]$and $\Omega_{\mathrm{CaCO}_{3}}$ in order to correctly estimate the impact of carbonate chemistry on net biotic $\mathrm{CaCO}_{3}$ formation.

Areas with corrosive conditions will expand under ocean acidification (Orr et al., 2005) so that $\mathrm{CaCO}_{3}$ dissolution becomes a more widespread problem for future calcifiers. However, dealing with the dissolution of $\mathrm{CaCO}_{3}$ is only of sec- 
ondary relevance for living organisms as everything that dissolves needs to be formed in the first place. Hence, although dissolution processes cannot be left unconsidered, it is reasonable from a biological point of view to focus on the processes that control the formation of $\mathrm{CaCO}_{3}$.

\subsubsection{Applicability of $\left[\mathrm{HCO}_{3}^{-}\right] /\left[\mathrm{H}^{+}\right]$in the geological record}

The restriction of $\left[\mathrm{HCO}_{3}^{-}\right] /\left[\mathrm{H}^{+}\right]$to gross calcification rates (see previous section) limits its applicability in the geological record because the information on $\mathrm{CaCO}_{3}$ accumulation conserved in the sediments is not only affected by gross calcification but also by post-production dissolution and abiotic modifications of $\mathrm{CaCO}_{3}$ during diagenesis, which are both controlled by $\Omega_{\mathrm{CaCO}_{3}}$. Thus, in order to verify the substrateinhibitor concept for the geological record we would need a reliable proxy for exclusively biotic gross calcification. Conversely, the application of $\Omega_{\mathrm{CaCO}_{3}}$ to explain trends in $\mathrm{CaCO}_{3}$ sedimentation (e.g., Hönisch et al., 2012; Ridgwell, 2005) would be reasonable because sedimentation involves both precipitation and dissolution and $\Omega_{\mathrm{CaCO}_{3}}$ is a good indicator of the former (under constant $T, S, P$ ) and the key parameter for the latter.

\subsubsection{Extreme concentrations of $\mathrm{HCO}_{3}^{-}$and $\mathrm{H}^{+}$}

In some studies, calcification rates correlated better with $\left[\mathrm{HCO}_{3}^{-}\right]$than with $\left[\mathrm{CO}_{3}^{2-}\right]$ (and thus $\left[\mathrm{HCO}_{3}^{-}\right] /\left[\mathrm{H}^{+}\right]$; Bach et al., 2013; Jury et al., 2010), which challenges the potential of $\left[\mathrm{HCO}_{3}^{-}\right] /\left[\mathrm{H}^{+}\right]$to serve as predictor variable for $\mathrm{CaCO}_{3}$ production. However, the dominant control on $\mathrm{HCO}_{3}^{-}$in these particular studies can be easily understood when considering the low $\mathrm{HCO}_{3}^{-}$concentrations at which its dominance actually occurred. The influence of $\left[\mathrm{HCO}_{3}^{-}\right]$relative to $\left[\mathrm{H}^{+}\right]$will become more and more influential under conditions where $\mathrm{HCO}_{3}^{-}$becomes increasingly limiting. Conversely, any influence of $\left[\mathrm{HCO}_{3}^{-}\right]$will become negligible when the organism is fully saturated with it. Under these circumstances calcification is most likely primarily controlled by $\left[\mathrm{H}^{+}\right]$(Bach et al., 2011; Jokiel 2011b; Taylor et al., 2011). Thus, the potential of $\left[\mathrm{HCO}_{3}^{-}\right] /\left[\mathrm{H}^{+}\right]$in predicting calcification is low at rather "extreme" carbonate-chemistry conditions where the influence of either $\mathrm{HCO}_{3}^{-}$or $\mathrm{H}^{+}$strongly outweighs the other. Its potential should be high, however, under conditions where the investigated organism is responsive to both $\left[\mathrm{HCO}_{3}^{-}\right]$and $\left[\mathrm{H}^{+}\right]$.

\subsubsection{Transport of seawater}

Some foraminifera and coral species have been reported to transfer calcification-relevant ions to the site of $\mathrm{CaCO}_{3}$ precipitation by means of seawater transport (Bentov et al., 2009; de Nooijer et al., 2009; Gagnon et al., 2012; Tambutté et al., 2012). In the case of foraminifera, seawater is engulfed in membrane vesicles, transported to the site of calcification, and on its way alkalized to increase $\left[\mathrm{CO}_{3}^{2-}\right]$ (Bentov et al., 2009; de Nooijer et al., 2009). In the case of corals, seawater (or at least its constituents smaller than $20 \mathrm{~nm}$; Tambutté et al., 2012) may pass epithelia and reach the $\mathrm{CaCO}_{3}$ skeleton via the paracellular pathway. For both processes (seawater endocytosis and seawater leakage along the intercellular space), all DIC species are potential inorganic carbon sources to fuel calcification. Hence, for organisms which purely rely on seawater endocytosis or leakage, the DIC : $[\mathrm{H}+]$ ratio proposed by Jokiel (2011a, b, 2013) could be more appropriate to explain the calcification response to carbonate chemistry than $\left[\mathrm{HCO}_{3}^{-}\right] /\left[\mathrm{H}^{+}\right]$.

\subsection{5 $\mathrm{CO}_{2}$ as an inorganic carbon source for calcification}

Some organisms receive significant amounts of inorganic carbon used for calcification from respiratory sources (Pearse, 1970; Erez, 1978; Sikes et al., 1981; Tanaka et al., 1986; Furla et al., 2000). Here, organisms do not exclusively rely on direct inorganic carbon utilization from seawater but supplement calcification to a variable degree with $\mathrm{CO}_{2}$ gained intracellularly from respired biomass. This $\mathrm{CO}_{2}$ utilization may be further strengthened (1) when metabolic $\mathrm{CO}_{2}$ is "trapped" inside the organisms through the establishment of $\mathrm{pH}$ gradients, which limit the diffusive loss of $\mathrm{CO}_{2}$ (Bentov et al., 2009, Glas et al., 2012b), or (2) when $\mathrm{CO}_{2}$ is transported actively towards the site of calcification (de Nooijer et al., 2014). Thus, $\mathrm{CO}_{2}$ reacting with $\mathrm{H}_{2} \mathrm{O}$ to form $\mathrm{HCO}_{3}^{-}$and $\mathrm{H}^{+}$(catalyzed by the ubiquitous enzyme carbonic anhydrase) could be an alternative inorganic carbon source for calcification in particular taxa. The potential control of seawater $\left[\mathrm{HCO}_{3}^{-}\right] /\left[\mathrm{H}^{+}\right]$on $\mathrm{CaCO}_{3}$ precipitation may therefore be weakened by the degree to which calcifiers utilize $\mathrm{CO}_{2}$ as an inorganic carbon source.

\subsubsection{Photoautotrophic calcifiers}

Photoautotrophic calcifiers such as coccolithophores or zooxanthellate corals not only interact with $\mathrm{HCO}_{3}^{-}$and $\mathrm{H}^{+}$but also with $\mathrm{CO}_{2}$. Photosynthetic and calcificationrelated processes are physiologically coupled within photoautotrophs (Paasche, 2002; Allemand et al., 2004). Accordingly, calcification rates will be affected indirectly when photosynthesis is $\mathrm{CO}_{2}$ limited (Bach et al., 2015). A valuable measure to determine the potential of $\mathrm{CO}_{2}$ to limit growth and photosynthesis is $\mathrm{K}_{1 / 2}$ which denotes the $\mathrm{CO}_{2}$ concentration where the process runs at half of its maximum. Available $\mathrm{K}_{1 / 2}$ measurements suggest that $\mathrm{CO}_{2}$ limitation mostly occurs well below $\mathrm{CO}_{2}$ concentrations typically encountered by the organisms in their respective habitats (Rost et al., 2003; Sett et al., 2014). Thus, its influence should rarely interfere with the influence of $\left[\mathrm{HCO}_{3}^{-}\right] /\left[\mathrm{H}^{+}\right]$under natural conditions. 


\section{Conclusions}

A variety of studies highlighted that carbonate chemistry controls calcification through the balance of stimulation by an inorganic carbon substrate $\left(\mathrm{HCO}_{3}^{-}\right.$or DIC) and inhibition by protons (e.g., Bach et al., 2011; Jokiel 2011a; Thomsen et al., 2015). Other studies found that $\left[\mathrm{CO}_{3}^{2-}\right]$ or $\Omega_{\mathrm{CaCO}_{3}}$ are the carbonate-chemistry parameters which best predict calcification (e.g., Schneider and Erez, 2006; de Putron et al., 2011; Gazeau et al., 2011; Waldbusser et al., 2014). The proportionalities between $\left[\mathrm{CO}_{3}^{2-}\right]$ or $\Omega_{\mathrm{CaCO}_{3}}$ and the $\left[\mathrm{HCO}_{3}^{-}\right] /\left[\mathrm{H}^{+}\right]$ratio derived in Eqs. (9) and (12) provide the chemical basis to reconcile these conflicting results. Every correlation between calcification and $\left[\mathrm{CO}_{3}^{2}\right]$ or $\Omega_{\mathrm{CaCO}_{3}}$ will be identical to the corresponding correlation with $\left[\mathrm{HCO}_{3}^{-}\right] /\left[\mathrm{H}^{+}\right]$when $T, S$, and $P$ are stable. Thus, the good correlations with $\left[\mathrm{CO}_{3}^{2-}\right]$ and $\Omega_{\mathrm{CaCO}_{3}}$ that have previously been reported may have simply masked the combined influence of $\left[\mathrm{HCO}_{3}^{-}\right]$and $\left[\mathrm{H}^{+}\right]$(see also findings by Jokiel, 2011a, b, 2013; Jokiel et al., 2014), which are arguably the physiologically more meaningful parameters to correlate gross calcification with (Bach et al., 2013; Jokiel, 2013; Thomsen et al., 2015; Sects. 3.1 and 3.3).

Accounting for the influence of $\left[\mathrm{HCO}_{3}^{-}\right] /\left[\mathrm{H}^{+}\right]$in controlling $\mathrm{CaCO}_{3}$ formation would also have interesting implications for how we assess carbonate-chemistry conditions and calcification along a latitudinal gradient. A comparison of present and future $\left[\mathrm{CO}_{3}^{2-}\right], \Omega_{\mathrm{CaCO}_{3}}$, and $\left[\mathrm{HCO}_{3}^{-}\right] /\left[\mathrm{H}^{+}\right]$patterns in the surface ocean revealed a strong poleward decline in $\left[\mathrm{CO}_{3}^{2-}\right]$ and $\Omega_{\mathrm{CaCO}_{3}}$ but no decline in $\left[\mathrm{HCO}_{3}^{-}\right] /\left[\mathrm{H}^{+}\right]$. These highly different latitudinal patterns are conserved during climate change. Thus, it may turn out that ocean acidification is globally a more uniform problem for biotic $\mathrm{CaCO}_{3}$ formation than previously thought.

Acknowledgements. I thank Kai Schulz and Ulf Riebesell for our frequent discussions about carbonate chemistry and calcification, which led to the preparation of this manuscript. I am also grateful to Toste Tanhua for support on CARINA data, Jan Taucher for sharing the UVic model output, and Allanah Paul and Jan Taucher for proofreading the manuscript. This study profited from the motivating and constructive reviews by Lennart de Nooijer, Paul Jokiel, and two anonymous reviewers. It was funded by the Federal Ministry of education and research (BMBF) in the framework of the Biological Impacts of Ocean Acidification II (BIOACID II) project (W.P. 1.3).

The article processing charges for this open-access publication were covered by a Research Centre of the Helmholtz Association.

Edited by: J. Middelburg

\section{References}

Agostini, S., Fujimura, H., Higuchi, T., Yuyama, I., Casareto, B. E., Suzuki, Y., and Nakano, Y.: The effects of thermal and high$\mathrm{CO}_{2}$ stresses on the metabolism and surrounding microenvironment of the coral Galaxea fascicularis., C. R. Biol., 336, 384-91, doi:10.1016/j.crvi.2013.07.003, 2013.

Allemand, D., Ferrier-Pagès, C., Furla, P., Houlbrèque, F., Puverel, S., Reynaud, S., Tambutté, É., Tambutté, S., and Zoccola, D.: Biomineralisation in reef-building corals: from molecular mechanisms to environmental control, C. R. Palevol, 3, 453-467, doi:10.1016/j.crpv.2004.07.011, 2004.

Bach, L. T., Riebesell, U., and Schulz, K. G.: Distinguishing between the effects of ocean acidification and ocean carbonation in the coccolithophore Emiliania huxleyi, Limnol. Oceanogr., 56, 2040-2050, doi:10.4319/lo.2011.56.6.2040, 2011.

Bach, L. T., Mackinder, L. C. M., Schulz, K. G., Wheeler, G., Schroeder, D. C., Brownlee, C., and Riebesell, U.: Dissecting the impact of $\mathrm{CO}_{2}$ and $\mathrm{pH}$ on the mechanisms of photosynthesis and calcification in the coccolithophore Emiliania huxleyi, New Phytol., 199, 121-34, doi:10.1111/nph.12225, 2013.

Bach, L. T., Riebesell, U., Gutowska, M. A., Federwisch, L., and Schulz, K. G.: A unifying concept of coccolithophore sensitivity to changing carbonate chemistry embedded in an ecological framework, Prog. Oceanogr., 135, 125-138, doi:10.1016/j.pocean.2015.04.012, 2015.

Beaufort, L., Probert, I., de Garidel-Thoron, T., Bendif, E. M., RuizPino, D., Metzl, N., Goyet, C., Buchet, N., Coupel, P., Grelaud, M., Rost, B., Rickaby, R. E. M., and de Vargas, C.: Sensitivity of coccolithophores to carbonate chemistry and ocean acidification., Nature, 476, 80-83, doi:10.1038/nature10295, 2011.

Bentov, S., Brownlee, C., and Erez, J.: The role of seawater endocytosis in the biomineralization process in calcareous foraminifera, Proc. Natl. Acad. Sci., 106, 21500-21504, 2009.

Boron, W. F.: Regulation of intracellular pH, Adv. Physiol. Educ., 28, 160-179, doi:10.1152/advan.00045.2004, 2004.

Buitenhuis, E. T., De Baar, H. J. W., and Veldhuis, M. J. W.: Photosynthesis and calcification by Emiliania huxleyi (Prymnesiophyceae) as a function of inorganic carbon species, J. Phycol., 35, 949-959, 1999.

Butler, J. N.: Ionic equilibrium: solubility and pH calculations, John Wiley and sons, New York, 1-576, 1998.

Cornwall, C. E., Hepburn, C. D., McGraw, C. M., Currie, K. I., Pilditch, C. A., Hunter, K. A., Boyd, P. W., and Hurd, C. L.: Diurnal fluctuations in seawater $\mathrm{pH}$ influence the response of a calcifying macroalga to ocean acidification, P. R. Soc. B, 280, 20132201, doi:10.1098/rspb.2013.2201, 2013.

Cyronak, T., Schulz, K. G. and Jokiel, P. L.: The Omega myth: what really drives lower calcification rates in an acidifying ocean, Ices J. Mar. Sci., fsv075, doi:10.1093/icesjms/fsv075, 2015.

de Nooijer, L. J., Langer, G., Nehrke, G., and Bijma, J.: Physiological controls on seawater uptake and calcification in the benthic foraminifer Ammonia tepida, Biogeosciences, 6, 2669-2675, doi:10.5194/bg-6-2669-2009, 2009.

de Nooijer, L. J., Spero, H. J., Erez, J., Bijma, J., and Reichart, G. J.: Biomineralization in perforate Foraminifera, Earth-Science Rev., 135, 48-58, doi:10.1016/j.earscirev.2014.03.013, 2014.

de Putron, S. J., McCorkle, D. C., Cohen, A. L., and Dillon, A. B.: The impact of seawater saturation state and bicarbonate ion con- 
centration on calcification by new recruits of two Atlantic corals, Coral Reefs, 30, 321-328, 2011.

Dickson, A. G.: Standard potential of the reaction: $\mathrm{AgCl}(\mathrm{s})+12$ $\mathrm{H}_{2}(\mathrm{~g})=\mathrm{Ag}(\mathrm{s})+\mathrm{HCl}(\mathrm{aq})$, and the standard acidity constant of the ion $\mathrm{HSO}_{4}^{-}$in synthetic sea water from 273.15 to $318.15 \mathrm{~K}, \mathrm{~J}$. Chem. Thermodyn., 22, 113-127, 1990.

Dickson, A. G.: The carbon dioxide system in seawater: equilibrium chemistry and measurements, in Guide to best practices for ocean acidification research and data reporting, edited by: Riebesell, U., Fabry, V. J., Hansson, L., and Gattuso, J.-P., Publications Office of the European Union, Luxembourg, 17-40, 2010.

Erez, J.: Vital effect on stable-isotope composition seen in foraminifera and coral skeletons, Nature, 273, 199-202, 1978.

Fabry, V., McClintock, J., Mathis, J., and Grebmeier, J.: Ocean acidification at high latitudes: the bellwether, Oceanography, 22, 160-171, doi:10.5670/oceanog.2009.105, 2009.

Flynn, K. J., Blackford, J. C., Baird, M. E., Raven, J. A., Clark, D. R., Beardall, J., Brownlee, C., Fabian, H., and Wheeler, G. L.: Changes in $\mathrm{pH}$ at the exterior surface of plankton with ocean acidification, Nat. Clim. Chang., 2, 510-513, 2012.

Furla, P., Galgani, I., Durand, I., and Allemand, D.: Sources and mechanisms of inorganic carbon transport for coral calcification and photosynthesis, J. Exp. Biol., 203, 3445-57, 2000.

Gagnon, A. C., Adkins, J. F., and Erez, J.: Seawater transport during coral biomineralization, Earth Planet. Sci. Lett., 329-330, 150161, doi:10.1016/j.epsl.2012.03.005, 2012.

Gazeau, F., Gattuso, J.-P., Greaves, M., Elderfield, H., Peene, J., Heip, C. H. R., and Middelburg, J. J.: Effect of carbonate chemistry alteration on the early embryonic development of the Pacific oyster (Crassostrea gigas), PLoS One, 6, e23010, doi:10.1371/journal.pone.0023010, 2011.

Glas, M. S., Fabricius, K. E., de Beer, D., and Uthicke, S.: The $\mathrm{O}_{2}, \mathrm{pH}$ and $\mathrm{Ca}^{2+}$ microenvironment of benthic foraminifera in a high $\mathrm{CO}_{2}$ world, PLoS One, 7, e50010, doi:10.1371/journal.pone.0050010, 2012a.

Glas, M. S., Langer, G., and Keul, N.: Calcification acidifies the microenvironment of a benthic foraminifer ( $\mathrm{Am}$ monia sp.), J. Exp. Mar. Bio. Ecol., 424-425, 53-58, doi:10.1016/j.jembe.2012.05.006, 2012b.

Hofmann, G. E., Barry, J. P., Edmunds, P. J., Gates, R. D., Hutchins, D. A., Klinger, T., and Sewell, M. A.: The effect of ocean acidification on calcifying organisms in marine ecosystems: an organism-to-ecosystem perspective, Annu. Rev. Ecol. Evol. Syst., 41, 127-147, 2010.

Hönisch, B., Ridgwell, A., Schmidt, D. N., Thomas, E., Gibbs, S. J., Sluijs, A., Zeebe, R., Kump, L., Martindale, R. C., Greene, S. E., Kiessling, W., Ries, J., Zachos, J. C., Royer, D. L., Barker, S., Marchitto, T. M., Moyer, R., Pelejero, C., Ziveri, P., Foster, G. L., and Williams, B.: The geological record of ocean acidification., Science, 335, 1058-1063, doi:10.1126/science.1208277, 2012.

Jokiel, P. L.: Ocean acidification and control of reef coral calcification by boundary layer limitation of proton flux, Bull. Mar. Sci., 87, 639-657, doi:10.5343/bms.2010.1107, 2011a.

Jokiel, P. L.: The reef coral two compartment proton flux model: A new approach relating tissue-level physiological processes to gross corallum morphology, J. Exp. Mar. Bio. Ecol., 409, 1-12, doi:10.1016/j.jembe.2011.10.008, 2011b.
Jokiel, P. L.: Coral reef calcification: carbonate, bicarbonate and proton flux under conditions of increasing ocean acidification, P. R. Soc. B, 280, 20130031, 2013.

Jokiel, P. L., Jury, C. P., and Rodgers, K. S.: Coral-algae metabolism and diurnal changes in the $\mathrm{CO}_{2}$-carbonate system of bulk sea water., PeerJ, 2, e378, doi:10.7717/peerj.378, 2014.

Jury, C. P., Whitehead, R. F., and Szmant, A. M.: Effects of variations in carbonate chemistry on the calcification rates of Madracis auretenra (= Madracis mirabilis sensu Wells, 1973): bicarbonate concentrations best predict calcification rates, Glob. Chang. Biol., 16, 1632-1644, 2010.

Keul, N., Langer, G., de Nooijer, L. J., and Bijma, J.: Effect of ocean acidification on the benthic foraminifera Ammonia sp. is caused by a decrease in carbonate ion concentration, Biogeosciences, 10, 6185-6198, doi:10.5194/bg-10-6185-2013, 2013.

Kleypas, J. A., Buddemeier, R. W., Archer, D., Gattuso, J.-P., Langdon, C., and Opdyke, B. N.: Geochemical consequences of increased atmospheric carbon dioxide on coral reefs, Science, 284, 118-120, 1999.

Langer, G., Geisen, M., Baumann, K.-H., Kläs, J., Riebesell, U., Thoms, S., and Young, J. R.: Species-specific responses of calcifying algae to changing seawater carbonate chemistry, Geochem. Geophy. Geosy., 7, Q09006, doi:10.1029/2005GC001227, 2006.

Lee, S.-K., Boron, W. F., and Parker, M. D.: Substrate specificity of the electrogenic sodium/bicarbonate cotransporter NBCe1-A (SLC4A4, variant A) from humans and rabbits., Am. J. Physiol. Renal Physiol., 304, F883-99, doi:10.1152/ajprenal.00612.2012, 2013.

Mackinder, L. C. M., Wheeler, G., Schroeder, D. C., Riebesell, U., and Brownlee, C.: Molecular mechanisms underlying calcification in coccolithophores, Geomicrobiol. J., 27, 585-595, 2010.

Mackinder, L., Wheeler, G., Schroeder, D., von Dassow, P., Riebesell, U., and Brownlee, C.: Expression of biomineralizationrelated ion transport genes in Emiliania huxleyi., Environ. Microbiol., 13, 3250-65, doi:10.1111/j.1462-2920.2011.02561.x, 2011.

Madshus, I. H.: Regulation of intracellular $\mathrm{pH}$ in eukaryotic cells, Biochem. J., 250, 1-8, 1988.

Mann, S.: Biomineralization: principles and concepts in bioinorganic materials chemistry, Oxford University Press, New York, 1-205, 2001.

Marubini, F., Ferrier-Pages, C., Furla, P., and Allemand, D.: Coral calcification responds to seawater acidification: a working hypothesis towards a physiological mechanism, Coral Reefs, 27, 491-499, 2008.

Melzner, F., Gutowska, M. A., Langenbuch, M., Dupont, S., Lucassen, M., Thorndyke, M. C., Bleich, M., and Pörtner, H.-O.: Physiological basis for high $\mathrm{CO}_{2}$ tolerance in marine ectothermic animals: pre-adaptation through lifestyle and ontogeny?, Biogeosciences, 6, 2313-2331, doi:10.5194/bg-6-2313-2009, 2009.

Millero, F. J.: Carbonate constants for estuarine waters, Mar. Freshw. Res., 61, 139-142, 2010.

Mucci, A.: The solubility of calcite and aragonite in seawater at various salinities, temperatures, and one atmosphere total pressure, Am. J. Sci., 283, 780-799, 1983.

Orr, J. C., Fabry, V. J., Aumont, O., Bopp, L., Doney, S. C., Feely, R. A., Gnanadesikan, A., Gruber, N., Ishida, A., Joos, F., Key, R. M., Keith, L., Maier-Reimer, E., Matear, R., Monfray, P., Mouchet, A., Najjar, R. G., Plattner, G.-K., Rodgers, K. B., Sabine, C. 
L., Sarmiento, J. L., Schlitzer, R., Slater, R. D., Totterdell, I. J., Weirig, M.-F., Yamanaka, Y., and Yool, A.: Anthropogenic ocean acidification over the twenty-first century and its impact on calcifying organisms, Nature, 437, 681-686, 2005.

Paasche, E.: A review of the coccolithophorid Emiliania huxleyi with particular reference to growth coccolith formation and calcification-photosynthesis interactions, Phycologia, 40, 503529, 2002.

Pearse, V. B.: Incorporation of metabolic $\mathrm{CO}_{2}$ into coral skeleton, Nature, 228, 383, doi:10.1038/228383a0, 1970.

Peltola, E., Wanninkhof, R., Feely, R. A., D., H., Castle, R., Greeley, D., Zhang, J.-Z., Millero, J., Gruber, N., Bullister, J. L., and Graham, T.: Inorganic and organic carbon, nutrient, and oxygen data from the R/V Ronald $\mathrm{H}$. Brown repeat hydrography cruise in the Atlantic ocean: CLIVAR $\mathrm{CO}_{2}$ section A16N_2003a (4 June-11 August, 2003), 2003.

Pushkin, A. and Kurtz, I.: SLC4 base $\left(\mathrm{HCO}_{3}^{-}, \mathrm{CO}_{3}^{2-}\right)$ transporters: classification, function, structure, genetic diseases, and knockout models, Am. J. Physiol. Physiol., 290, 580-599, 2006.

Ridgwell, A.: A Mid Mesozoic Revolution in the regulation of ocean chemistry, Mar. Geol., 217, 339-357, doi:10.1016/j.margeo.2004.10.036, 2005.

Romero, M. F., Chen, A.-P., Parker, M. D., and Boron, W. F.: The SLC4 family of bicarbonate transporters, Mol. Aspects Med., 34, 159-182, 2013.

Rost, B., Riebesell, U., Burkhardt, S., and Sültemeyer, D.: Carbon acquisition of bloom-forming marine phytoplankton, Limnol. Oceanogr., 48, 55-67, 2003.

Schmittner, A., Oschlies, A., Matthews, H. D., and Galbraith, E. D.: Future changes in climate, ocean circulation, ecosystems, and biogeochemical cycling simulated for a business-as-usual $\mathrm{CO}_{2}$ emission scenario until year $4000 \mathrm{AD}$, Global Biogeochem. Cy., 22, GB1013, doi:10.1029/2007GB002953, 2008.

Schneider, K. and Erez, J.: The effect of carbonate chemistry on calcification and photosynthesis in the hermatypic coral Acropora eurystoma, Limnol. Oceanogr., 51, 1284-1293, 2006.

Schulz, K. G. and Riebesell, U.: Diurnal changes in seawater carbonate chemistry speciation at increasing atmospheric carbon dioxide, Mar. Biol., 160, 1889-1899, doi:10.1007/s00227-0121965-y, 2013.

Schulz, K. G., Riebesell, U., Rost, B., Thoms, S., and Zeebe, R. E.: Determination of the rate constants for the carbon dioxide to bicarbonate inter-conversion in $\mathrm{pH}$-buffered seawater systems, Mar. Chem., 100, 53-65, doi:10.1016/j.marchem.2005.11.001, 2006.

Schulz, K. G., Barcelos e Ramos, J., Zeebe, R. E., and Riebesell, $\mathrm{U}$.: $\mathrm{CO}_{2}$ perturbation experiments: similarities and differences between dissolved inorganic carbon and total alkalinity manipulations, Biogeosciences, 6, 2145-2153, doi:10.5194/bg-6-21452009, 2009.

Sett, S., Bach, L. T., Schulz, K. G., Koch-Klavsen, S., Lebrato, M., and Riebesell, U.: Temperature modulates coccolithophorid sensitivity of growth, photosynthesis and calcification to increasing seawater $p \mathrm{CO}_{2}$., PLoS One, 9, e88308, doi:10.1371/journal.pone.0088308, 2014.

Shaw, E. C., Munday, P. L., and McNeil, B. I.: The role of $\mathrm{CO}_{2}$ variability and exposure time for biological impacts of ocean acidification, Geophys. Res. Lett., 40, 4685-4688, 2013.
Sikes, C. S., Okazaki, K., and Fink, R. D.: Respiratory $\mathrm{CO}_{2}$ and the supply of inorganic carbon for calcification of sea urchin embryos, Comp. Biochem. Physiol. A, 70, 285-291, 1981.

Stumpp, M., Hu, M. Y., Melzner, F., Gutowska, M. A., Dorey, N., Himmerkus, N., Holtmann, W. C., Dupont, S. T., Thorndyke, M. C., and Bleich, M.: Acidified seawater impacts sea urchin larvae $\mathrm{pH}$ regulatory systems relevant for calcification, Proc. Natl. Acad. Sci., 109, 18192-19197, 2012.

Takahashi, T., Olafsson, J., Goddard, J. G., Chipman, D. W., and Sutherland, S. C.: Seasonal variation of $\mathrm{CO}_{2}$ and nutrients in the high-latitude surface oceans: A comparative study, Global Biogeochem. Cy., 7, 843-878, 1993.

Tambutté, E., Tambutté, S., Segonds, N., Zoccola, D., Venn, A., Erez, J., and Allemand, D.: Calcein labelling and electrophysiology: insights on coral tissue permeability and calcification., Proc. Biol. Sci., 279, 19-27, doi:10.1098/rspb.2011.0733, 2012.

Tanaka, N., Monaghan, M. C., and Rye, D. M.: Contribution of metabolic carbon to mollusc and barnacle shell carbonate, Nature, 320, 520-523, 1986.

Taucher, J. and Oschlies, A.: Can we predict the direction of marine primary production change under global warming?, Geophys. Res. Lett., 38, 1-6, doi:10.1029/2010GL045934, 2011.

Taylor, A. R., Chrachri, A., Wheeler, G., Goddard, H., and Brownlee, C.: A voltage-gated $\mathrm{H}^{+}$channel underlying $\mathrm{pH}$ homeostasis in calcifying coccolithophores., PLoS Biol., 9, e1001085, doi:10.1371/journal.pbio.1001085, 2011.

Taylor, A. R., Brownlee, C., and Wheeler, G. L.: Proton channels in algae: reasons to be excited, Trends Plant Sci., 17, 675-84, doi:10.1016/j.tplants.2012.06.009, 2012.

Thomsen, J., Gutowska, M. A., Saphörster, J., Heinemann, A., Trübenbach, K., Fietzke, J., Hiebenthal, C., Eisenhauer, A., Körtzinger, A., Wahl, M., and Melzner, F.: Calcifying invertebrates succeed in a naturally $\mathrm{CO}_{2}$-rich coastal habitat but are threatened by high levels of future acidification, Biogeosciences, 7, 3879-3891, doi:10.5194/bg-7-3879-2010, 2010.

Thomsen, J., Haynert, K., Wegner, K. M., and Melzner, F.: Impact of seawater carbonate chemistry on the calcification of marine bivalves, Biogeosciences, 12, 4209-4220, doi:10.5194/bg12-4209-2015, 2015.

Van Heuven, S., Pierrot, D., Rae, J. W. B., Lewis, E., and Wallace, D. W. R.: MATLAB Program Developed for $\mathrm{CO}_{2}$ System Calculations, ORNL/CDIAC-105b, 2011.

Venn, A. A., Tambutté, E., Holcomb, M., Laurent, J., Allemand, D., and Tambutté, S.: Impact of seawater acidification on $\mathrm{pH}$ at the tissue-skeleton interface and calcification in reef corals, P. Natl. Acad. Sci. USA, 110, 1634-1639, doi:10.1073/pnas.1216153110, 2013.

Waldbusser, G. G., Hales, B., Langdon, C. J., Haley, B. A., Schrader, P., Brunner, E. L., Gray, M. W., Miller, C. a., and Gimenez, I.: Saturation-state sensitivity of marine bivalve larvae to ocean acidification, Nature Climate Change, 5, 273-280, doi:10.1038/nclimate2479, 2014.

Wanninkhof, R., Doney, S. C., Peltola, E., Castle, R., Millero, J., Bullister, J. L., D., H., Warner, M. J., Langdon, C., Johnson, G. C., and Mordy, C. W.: Carbon dioxide, hydrographic, and chemical data obtained during the R/V Ronald H. Brown repeat hydrography cruise in the Atlantic Ocean: CLIVAR $\mathrm{CO}_{2}$ Section A16S_2005 (11 January-24 February, 2005), 2006. 
Weiner, S. and Addadi, L.: Crystallization pathways in biomineralization, Annu. Rev. Mater. Res., 41, 21-40, 2011.

Wolf-Gladrow, D. and Riebesell, U.: Diffusion and reactions in the vicinity of plankton: a refined model for inorganic carbon transport, Mar. Chem., 59, 17-34, 1997.
Zeebe, R. E. and Wolf-Gladrow, D. A.: $\mathrm{CO}_{2}$ in seawater: Equilibrium, kinetics, isotopes, Elsevier Oceanography Series, Amsterdam, 1-346, 2001. 